similar to that for morphological susceptibility of the central nervous system (15). (iv) Agents which are teratogenic to non-central nervous system structures are not behavioral teratogens (16). (v) Genotype interacts with the agent in determining the behavioral effects [see $(12$ 13)]. (vi) The extent of the behavioral effect is dependent on the dose of the agent (11). The results of our experiments allow us to add two more working principles. (vii) Some agents that are behavioral teratogens are apparently not structurally teratogenic. (viii) Some behavioral teratogens may be called "pure," in that they can produce behavioral abnormalities without accompanying alterations in growth or other physical measures of postnatal vitality.

The data suggest that among the drugs tested herein, propoxyphene appears to meet the criteria for being a pure behavioral teratogen. This conclusion is at best preliminary and should not be extrapolated to humans. Prochlorperazine and fenfluramine were also found to be behavioral teratogens, but they had reproductive and growth effects that foreshadowed the untoward behavioral outcomes. It was not anticipated, however, that the drug with the most severe reproductive effects, prochlorperazine, would show the fewest behavioral effects in the survivors. This observation adds credence to the tenet that behavior repre- sents a different sphere of effects not readily predicted from traditional toxicological end points, at least with current methods.

\section{References and Note}

1. D. E. Hutchings, in Studies on the Developmen of Behavior and the Nervous System, vol. 4 Early Influences, G. Gottlieb, Ed. (Academic

2. K. L. Jones and D. W. Smith, Lancet 1973-II, 999 (1973); S. K. Clarren, E. C. Alvord, S. M Sumi, A. P. Streissguth, J. Pediatr. 92, 64 (1978), S. K. Clarren and D. W. Smith, N. Engl. . Med. 298, 1063 (1978); A. P. Streissguth, C. S. Herman, D. W. Smith, J. Pediatr. 92, 363 (1978); J. W. Hanson, A. P. Streissguth, D. W. Smith, ibid., p. 457; J. W. Hanson and D. W mith, ibid. 87, 285 (1975); G. L. Feldman, D. D. Weaver, E. W. Lovrien, Am. J. Dis. Child.

. S. Kandall, in Drug Abuse in Pregnancy and Neonatal Effects, J. L. Rementaria, Ed. (Mosby, St. Louis, 1977), p. 116; Y. Brackbill, Dev.
Psychobiol. 10, 529 (1977).

(1974).

Psychopharmacol. 1, 3 (1977)

6. D. L. Gilbert, B. V. Franko, J. W Ward, G. Woodward, K. D. Courtney, Toxicol Appl. Pharmacol. 19, 705 (1971); J. L Toxicol. Appl. V. Owen, G. R. Koenig, J. K. Markham, R. C Anderson ibid., p. 471; J. G. Wilson, in HandAnderson ibid., p. 471; J. G. Wilson, in Hand. 309 .

7. C. V. Vorhees, R. E. Butcher, R. L. Brunner, T. J. Sobotka, Toxicol. Appl. Pharmacol., in McDaniel, R. E. Butcher, Teratology 17.271 1978); R. L. Brunner, M. S. McLean, C. V. Vorhees, R. E. Butcher, ibid. 18, 379 (1978); R. L. Brunner, C. V. Vorhees, L. Kinney, R. E. Butcher, Neurobehav. Toxicol. 1,79 (1979)

8. S. Zamenhof, H. Bursztyn, K. Rich, P. J. Zamenhof, J. Neurochem. 11, 505 (1964); O. H. Lowry, N. J. Rosenbrough, A. L. Farr, R. J. Randall, J. Biol. Chem. 193, 265 (1951).

9. R. E. Kirk, Experimental Design: Procedures mont, Calif., 1968); C. Y. Kramer, Biometrics 12, 307 (1956)

10. J. P. Guilford, Fundamental Statistics in Psychology and Education (McGraw-Hill, New York, 1965).

11. R. E. Butcher, C. V. Vorhees, C. A. Kimmel, Nature (London) New Biol. 236, 211 (1972); R. E. Butcher, W. J. Scott, K. Kazmaier, E. J. Ritter, Teratology 7, 161 (1973); R. E. Butcher, K. Hawver, K. Kazmaier, W. Scott, in Basic and Therapeutic Aspects of Perinatal Pharmacology, P. L. Morselli, S. Garattini, F. Sereni, Eds. Raven, New York, 1975), p. 171; C. A. Kimmel, R. E. Butcher, C. V. Vorhees, H. J. Schumacher, Teratology 10, 293 (1974); J. M. Spyker, S. B. Sparber, A. M. Goldberg, Science 177, 621 (1972)

12. R. E. Butcher, R. L. Brunner, T. Roth, C. A Kimmel, Life Sci. 11, 141 (1972)

13. C. V. Vorhees, Teratology 10, 269 (1974)

4. P. M. Rodier, ibid. 16, 235 (1977); D. E. Hutchings, J. Gibbon, M. A. Kaufman, Dev. Psychobiol. 6, 445 (1973); D. E. Hutchings and J. Gaston, ibid. 7, 225 (1974).

15. P. M. Rodier, S. S. Reynolds, W. N. Roberts, Teratology 19, 327 (1979); C. V. Vorhees et al., ibid. 17, 271 (1978)

16. R. E. Butcher, K. Hawver, T. Burhacher, W. Scott, in Aberrant Development in Infancy, $\mathrm{N}$ Ellis, Ed. (Erlbaum, Potomac, Md., 1975), p. 147 .

17. R. E. Butcher, C. V. Vorhees, C. W. Kindt, K J. Kazmaier-Novak, H. K. Berry, Pharmacol. Biochem. Behav. 7, 129 (1977); W. C. Biel, J. Genet. Psychol. 56, 439 (1940).

18. L. Kinney and C. V. Vorhees, Pharmacol. Biochem. Behav. 10, 437 (1979).

19. Preliminary reports of these data were presented at the Teratology Society meetings, Mackinac Island, Mich., June 1978, the Society for Research in Child Development, San Francisco Calif., March 1979, and the Environmental Protection Agency Workshop on Methods in $\mathrm{Be}$ Tex., April 1979. This work was supported by FDA., April 1979. This work was supported by 05221. We acknowledge S. Krop of the FDA. $H$. $\mathrm{K}$. Berry, director of the Division of Ind, $\mathrm{H}$. rors of Metabolism, and L. Jonas, statistical assistant, for their invaluable contributions to this project. We also thank Smith Kline \& French, A. H. Robins, and Eli Lilly \& Co. for their donations of prochlorperazine, fenfluramine, and propoxyphene.

\title{
Geographic Constraints on Women's Careers in Academia
}

\author{
Gerald Marwell, Rachel Rosenfeld, Seymour Spilerman
}

Recent federal legislation $(I)$ requires institutions of higher education to correct their discriminatory practices against women. Court decisions have made it clear that "statistics can be used as prima facie evidence of discrimination" (2). The statistics to show that women have fared less well than men in academia are available in quantity. Women have been at lower academic ranks and in less prestigious positions, have taken longer to advance, and have SCIENCE, VOL. 205, 21 SEPTEMBER 1979 received lower pay than men (3-9). As many writers on this subject realize, factors other than the policies and decisions of educational institutions contribute to these differences. Attention has tended to focus on personal attributes such as age and publication record. Still, some commentators [see, for example, (10) and (11)] imply that discrimination accounts for all status differences between male and female academics, and others attribute all the residual differences be- tween males and females, after personal attributes are taken into consideration, to the same source (9).

In contrast, we shall argue that a considerable part of the disparity between men and women in academic status and earnings derives from neither of those sources but from the disadvantages that marriage imposes on the women. In a two-career family many crucial decisions (for example, whether or not to have children and where to reside) can have an adverse effect on one or both careers. In this situation, two-career couples will be at a handicap, in comparison with one-career couples, with respect to maximizing job prospects. We will argue that, in the aggregate, in academia women's careers suffer more as a result than men's.

The factors of particular interest in

Dr. Marwell and Dr. Spilerman are professors of sociology, the former at the University of Wisconsin, Madison 53706, the latter at Columbia Universidirector at the National Opinion Research Center University of Chicago, Chicago, Illinois 60637, and University of Chicago, Chicago, Illinois 60637, and University, Montreal, Canada H3C 3G1. 
this article are choice of residence community and pattern of geographic change. We shall show that academic women are more likely than academic men to work in large metropolitan places, and less likely than men to tunities and make job shifts when and where they appear. This requires the flexibility to make geographic moves, especially early in the course of one's career $(7,15)$.

On average, academic women are

Summary. Male and female academics have very different residence patterns. Women are more concentrated in our largest urban centers; also, wherever they reside, women are less likely than men to change communities when changing institutions. Much of this sex difference is attributable to the constraints under which married academic women must manage their careers, in particular the requirements of twocareer households. The authors argue that the status difference between men and women in academia is attributable, in part, to the geographic limitations on the locations of married women, as these prevent making strategic job changes to advance career prospects.

change geographic areas when they change jobs. Marked geographic preferences on the part of women should result in lower rates of attainment even in the absence of discrimination by universities and colleges (12). Job switching is the rule in academic careers, and it pays off in upward mobility $(4,13)$. Since academia is essentially a national labor market in specialized positions (14), one must take advantage of strategic oppor-

more constrained than academic men in taking advantage of these strategic opportunities. To a considerable degree this is due to the custom in our society of marriage hypergamy, the tendency for women to marry men of higher (or at least not lower) status than their own. As a consequence, almost all married women in academia have husbands who are also pursuing careers, mostly professional careers. Comparatively few male aca-

Table 1. Percentage distribution of faculty members of each sex in various departments, by size of urban area in which employing institution is located (38). Only Ph.D.'s are included.

\begin{tabular}{|c|c|c|c|c|c|c|}
\hline \multirow[b]{2}{*}{ Sex } & \multirow[b]{2}{*}{$N$} & \multicolumn{5}{|c|}{ Size of urban area in which institution is located* } \\
\hline & & $\begin{array}{c}\text { Less } \\
\text { than } \\
100,000\end{array}$ & $\begin{array}{c}100,000 \\
\text { to } \\
250,000\end{array}$ & $\begin{array}{c}250,000 \\
\text { to } \\
1 \text { million }\end{array}$ & $\begin{array}{l}1 \text { million } \\
\text { to } \\
2 \text { million }\end{array}$ & $\begin{array}{c}\text { More } \\
\text { than } \\
2 \text { million }\end{array}$ \\
\hline \multicolumn{7}{|c|}{ All departments } \\
\hline Men & 27,007 & 40.6 & 17.7 & 15.1 & 3.7 & 22.8 \\
\hline Women & 2,409 & 32.9 & 14.6 & 15.2 & 5.8 & 31.5 \\
\hline \multicolumn{7}{|c|}{ Biological sciences } \\
\hline Men & 3,234 & 42.9 & 17.4 & 15.6 & 4.4 & 19.7 \\
\hline Women & 298 & 29.2 & 12.8 & 14.8 & 7.0 & 36.2 \\
\hline \multicolumn{7}{|c|}{ Education } \\
\hline Men & 975 & 40.2 & 20.7 & 15.9 & 2.6 & 20.6 \\
\hline Women & 196 & 32.1 & 14.8 & 17.3 & 6.1 & 29.6 \\
\hline \multicolumn{7}{|c|}{ Fine arts } \\
\hline Men & 826 & 42.9 & 16.2 & 16.3 & 2.4 & 22.2 \\
\hline Women & 112 & 31.3 & 19.6 & 13.5 & 2.7 & 33.0 \\
\hline \multicolumn{7}{|c|}{ Humanities and languages } \\
\hline Men & 5,213 & 40.5 & 15.9 & 14.9 & 3.6 & 25.0 \\
\hline Women & 752 & 31.5 & 12.9 & 15.8 & 5.1 & 34.7 \\
\hline \multicolumn{7}{|c|}{ Physical sciences } \\
\hline Men & 3,806 & 42.0 & 14.5 & 15.1 & 3.5 & 24.9 \\
\hline Women & 136 & 27.2 & 9.6 & 17.6 & 8.1 & 37.5 \\
\hline \multicolumn{7}{|c|}{ Psychology } \\
\hline Men & 1,337 & 42.0 & 18.2 & 15.8 & 3.7 & 20.3 \\
\hline Women & 170 & 37.1 & 11.8 & 12.3 & 6.5 & 32.4 \\
\hline \multicolumn{7}{|c|}{ Social sciences } \\
\hline Men & 2,884 & 40.0 & 15.6 & 14.2 & 4.9 & 25.3 \\
\hline Women & 207 & 30.0 & 8.7 & 12.5 & 7.7 & 41.1 \\
\hline
\end{tabular}

*Based on the 1960 U.S. Census definition of "urbanized area."

1226 demics are in such two-career marriages $(3,16)$. With regard to geographic mobility, membership in a two-career family can affect career development adversely in at least two ways: one member may be unable to accept a good offer in another city because the career of the spouse cannot develop there; or one member may have to relinquish a good position for a less desirable job elsewhere, in order to move with the spouse.

Because a greater proportion of academic women than academic men have spouses in professional careers, in the aggregate academic women would be more hindered in their career progress even if the difficulties of organizing a two-career household were to fall equally on both spouses. But it is the case that the career costs tend to be borne disproportionately by the wife, because couples commonly place the needs of the husband's career first in deciding on geographic moves (17). For example, in a sample of Ph.D.'s and Ed.D.'s, Centra $(6$, p. 118) found that 49 percent of the married women and 4 percent of the married men viewed their spouses' jobs as a major deterrent to considering positions in other geographic areas $(18,19)$. Also, Reskin (20) and Curtis (21) report a marked tendency for women Ph.D.'s to spend prolonged periods on postdoctoral grants, which enable them to arrange to work where it suits the needs of their families. We also note that since women tend to be younger than their husbands, they often must develop careers in the context of their húsbands' existing work commitments.

Thus, the tendency for academic women to be concentrated in lowerranked positions than academic men derives from at least three factors: the constraints on both partners of two-career families, a marital condition more common among professional women than professional men; the tendency for decisions within such a family to be directed toward maximizing the husband's career prospects; and the discriminatory practices against women by colleges and universities. We focus in this article on the residence patterns of academic women and sketch the implications of restrictions on their geographic mobility for career development.

The narrow implications of the greater constraints upon married academic women are twofold: (i) they should be less likely than their male colleagues to move, and (ii) in looking for new appointments they would be compelled to seek positions in locations offering large labor markets so that both spouses could SCIENCE, VOL. 205 
find satisfactory jobs. A small community such as Ann Arbor, Madison, or Austin contains only one major academic institution and generally has restricted opportunities for employment (22). Metropolitan places such as New York City or Los Angeles, by contrast, each contain several universities and colleges and therefore provide multiple options for the partners in a two-career academic household. We therefore expect such couples to locate more frequently in large communities. Once the members of such a family have obtained a jointly satisfactory situation, either may be constrained from moving if it is at the expense of the other's position. Hence, such couples should be less mobile geographically than families with only one career-oriented spouse.

In summary, we intend to show that male and female academics respond differently to the geographic aspects of jobs, women being (i) more likely to settle in large metropolitan areas and (ii) less likely to move between geographic locales when changing jobs. If these propositions are correct, and the effects strong, they suggest a structural source for some of the disparity between the achievements of males and females in academia which is not related to institutional discrimination.

\section{Geographic Locations of \\ Male and Female Academics}

Information pertaining to residence patterns was obtained from the Carnegie Commission's 1969 survey of college and university faculty in the United States. In Table 1 we report city-size distributions, by sex, of a representative sample of faculty members, all holders of the $\mathrm{Ph}$.D.; alongside we present comparable statistics for seven selected disciplines (subsamples) which contain large numbers of women and appear to us to provide contrasts of interest. In each of the seven disciplines, and in the total sample as well, there is evidence of a substantially higher concentration of female faculty members than of male in large urban centers (23). In the total sample 37.3 percent of the women and 26.5 percent of the men were employed in communities with one million or more inhabitants. In psychology, the discipline on which much of our analysis will be based, the proportions are 38.9 and 24 percent.

Forty-four percent of the women and 90 percent of the men in the total samples were married at the time of the sur21 SEPTEMBER 1979 vey. In the subsample of psychologists the proportions were 58 and 90 percent. Because married women academics are much more likely than men to be in twocareer families, one way to assess the consequences of such a union for geographic location is to examine the relationship between sex and city size, controlling on marital status. That is, although we do not know the occupations of the spouses of individuals in the sample, we may usefully consider the category "female-married" as a proxy for two-career couples. It is apparent in Table 2 that the effect of marriage on the city-size locations of women is pronounced and in the direction suggested by our argument. In the total sample, married females were nearly twice as likely as married males to reside in urban places with population exceeding one million. Among psychologists the difference was equally large.

The geographic distributions of single academics show much smaller differences between the sexes, and the direction is reversed: 31.4 percent of single females and 38.2 percent of single males in the total sample resided in communities greater than one million; and in the psychologist subsample 33.8 percent of single females and 35.5 percent of single males were in such cities. These results are consistent with our thesis about the constraining effects of two-career households. Single individuals may or may not prefer metropolitan places, but they are not restricted by conjugal ties, as married women (or two-career couples) often are, and are therefore freer to accept offers from institutions in small communities.

Table 2. Percentage distribution of faculty members of each sex and marital status, in all departments combined and in psychology departments, by size of urban area in which employing institution is located (38). Only Ph.D.'s are included.

\begin{tabular}{|c|c|c|c|c|c|c|}
\hline \multirow{2}{*}{$\begin{array}{l}\text { Marital } \\
\text { status } \\
\text { at time } \\
\text { of survey }\end{array}$} & \multirow[b]{2}{*}{$N$} & \multicolumn{5}{|c|}{ Size of urban area in which institution is located } \\
\hline & & $\begin{array}{l}\text { Less } \\
\text { than } \\
100,000\end{array}$ & $\begin{array}{c}100,000 \\
\text { to } \\
250,000\end{array}$ & $\begin{array}{c}250,000 \\
\text { to } \\
1 \text { million }\end{array}$ & $\begin{array}{l}1 \text { million } \\
\text { to } \\
2 \text { million }\end{array}$ & $\begin{array}{c}\text { More } \\
\text { than } \\
2 \text { million }\end{array}$ \\
\hline
\end{tabular}

\begin{tabular}{|c|c|c|c|c|c|c|}
\hline \multicolumn{7}{|c|}{ All departments } \\
\hline \multicolumn{7}{|l|}{ Married } \\
\hline Men & 24,355 & 41.6 & 18.0 & 15.0 & 3.5 & 21.8 \\
\hline Women & 1,060 & 30.7 & 12.1 & 12.3 & 6.6 & 38.4 \\
\hline \multicolumn{7}{|c|}{ Not married } \\
\hline Men & 2,652 & 31.2 & 14.5 & 16.2 & 5.4 & 32.8 \\
\hline Women & 1,349 & 34.6 & 16.6 & 17.5 & 5.2 & 26.2 \\
\hline \multicolumn{7}{|c|}{ Psychology } \\
\hline \multicolumn{7}{|l|}{ Married } \\
\hline Men & 1,200 & 43.3 & 18.8 & 15.3 & 3.4 & 19.3 \\
\hline Women & 97 & 36.1 & 13.4 & 9.4 & 6.2 & 35.1 \\
\hline \multicolumn{7}{|c|}{ Not married } \\
\hline Men & 135 & 31.9 & 13.3 & 19.2 & 5.9 & 29.6 \\
\hline Women & 71 & 39.4 & 9.9 & 16.8 & 5.6 & 28.2 \\
\hline
\end{tabular}

1227 
prevailed for psychologists with Ph.D.'s. This design permits us to compare the attainments of individuals with a like number of years of work experience and some attachment to academia.

To find women with these characteristics efficiently we employed the 197172 Survey of Women Members of the American Psychological Association. Of the 5098 women listed, 207 met our conditions and had sufficient information in the 1970 directory for the analyses (26). A sample of 207 men was then selected from the directory to match the 207 women on three characteristics (27): (i) age at receiving the Ph.D. (35 or young- er, or older than 35); (ii) type of employment history (nonclinical or clinical); and (iii) quality of graduate department from which the Ph.D. was obtained ("distinguished," "strong," or "other"') as rated in Cartter (28). This sample thus broadly controls for the fact that women are, on average, older than men when they receive their doctorates, for the greater tendency of men to have careers that include other than strictly academic positions, and for the effect of quality of degree-granting institution on job history. Men were also matched to women by alphabetical order of last name, as a rough control for ethnic differences.

Table 3. Percentage distribution of psychologists of each sex at three points in their careers, by size of urban area of their institutions at those points. [Data from (24)]

\begin{tabular}{|c|c|c|c|c|c|c|}
\hline \multirow[b]{2}{*}{ Sex } & \multirow[b]{2}{*}{$N$} & \multicolumn{5}{|c|}{ Size of urban area in which institution is located* } \\
\hline & & $\begin{array}{c}\text { Less } \\
\text { than } \\
100,000\end{array}$ & $\begin{array}{c}100,000 \\
\text { to } \\
250,000\end{array}$ & $\begin{array}{c}250,000 \\
\text { to } \\
1 \text { million }\end{array}$ & $\begin{array}{l}1 \text { million } \\
\text { to } \\
2 \text { million }\end{array}$ & $\begin{array}{c}\text { More } \\
\text { than } \\
2 \text { million }\end{array}$ \\
\hline \multicolumn{7}{|c|}{ Ph.D. awarded } \\
\hline Men & 207 & 20.8 & 23.2 & 18.3 & 9.7 & 28.0 \\
\hline Women & 207 & 18.4 & 18.8 & 17.4 & 9.7 & 35.7 \\
\hline \multicolumn{7}{|c|}{ First job after Ph.D } \\
\hline Men & $206 \dagger$ & 29.6 & 16.0 & 15.6 & 9.7 & 29.1 \\
\hline Women & $199 \dagger$ & 18.6 & 12.6 & 19.1 & 9.0 & 40.7 \\
\hline \multicolumn{7}{|c|}{ Job 8 years after Ph.D } \\
\hline Men & 207 & 25.6 & 12.1 & 22.7 & 8.7 & 30.9 \\
\hline Women & $203 \dagger$ & 17.7 & 13.8 & 21.2 & 10.8 & 36.5 \\
\hline
\end{tabular}

*Based on the 1960 U.S. Census definition of "urbanized area." Size of Canadian cities was taken from the 1960 Canadian Census. thess than 207 because location of some jobs was not reported.

Table 4. Percentage of psychologists of each sex who remained in urban area of Ph.D.-granting institution for first job after receiving the Ph.D. [Data from (24)]

\begin{tabular}{|c|c|c|c|c|}
\hline \multirow{2}{*}{$\begin{array}{c}\text { Size of urban area } \\
\text { in which Ph.D.-granting } \\
\text { institution is located }\end{array}$} & \multicolumn{2}{|c|}{ Men } & \multicolumn{2}{|c|}{ Women } \\
\hline & $N$ & $\begin{array}{l}\text { \% whose first } \\
\text { job was in } \\
\text { same area }\end{array}$ & $N$ & $\begin{array}{l}\text { \% whose first } \\
\text { job was in } \\
\text { same area }\end{array}$ \\
\hline Less than 100,000 & 43 & 16.3 & 36 & 16.7 \\
\hline 100,000 to 250,000 & 48 & 22.9 & 38 & 42.1 \\
\hline 250,000 to 1 million & 38 & 21.1 & 33 & 33.3 \\
\hline 1 million to 2 million & 20 & 35.0 & 19 & 31.6 \\
\hline More than 2 million & 57 & 56.1 & 73 & 72.6 \\
\hline All places & $206^{*}$ & 31.6 & $199 *$ & 46.2 \\
\hline
\end{tabular}

*Less than 207 because location of some jobs was not reported.

Table 5. Percentage of job shifts by psychologists of each sex that did not entail change of urban area. Job shift is defined as a change of institution. Data are based on the first 8 to 15 years after receipt of the Ph.D. (see text). [Data from (24)]

\begin{tabular}{lcccr}
\hline $\begin{array}{c}\text { Size of urban area in } \\
\text { which first of a pair } \\
\text { of jobs was held }\end{array}$ & $N$ & $\begin{array}{c}\text { \% within } \\
\text { same area }\end{array}$ & & \multicolumn{2}{c}{ Women's job shifts } \\
\cline { 2 - 4 } \cline { 5 - 5 } & 93 & 11.8 & 53 & $\begin{array}{c}\% \text { within } \\
\text { same area }\end{array}$ \\
\hline $\begin{array}{l}\text { Less than 100,000 } \\
100,000 \text { to 250,000 }\end{array}$ & 32 & 6.3 & 36 & 5.7 \\
250,000 to 1 million & 48 & 8.3 & 38 & 33.3 \\
1 million to 2 million & 32 & 18.8 & 30 & 33.3 \\
More than 2 million & 81 & 48.1 & 102 & 46.7 \\
All job shifts & 286 & 21.7 & 269 & 66.7 \\
\hline
\end{tabular}

1228

While this sample allows us to focus on sex differences in geographic and career mobility, it imposes limits on generalization. The subsample of 207 women is not representative of the 1955 to 1962 cohort of women psychologists with Ph.D.'s, since it does not include women who dropped out of academia or the labor force. The men are not representative of their Ph.D. cohort because they were chosen according to proportions set by the women's sample. Finally, the APA directory does not report marital status; our analysis must therefore be limited to gross comparisons between women and men, instead of being based on refined comparisons between married women and other individuals (29).

As a bridge between the two data sets, we present in Table 3 the city-size locations of members of our second sample, in a form comparable to Table 1 . Since we have more information, we show locations at three points in the careers: during graduate training, in first job after receiving the $\mathrm{Ph}$.D., and 8 years after receiving the Ph.D. These results are not quite so strong as in the Carnegie sample, but they consistently support our argument that women academics tend to reside in large communities. The findings are most striking with respect to first job, but the effect is present in each of the distributions.

The slightly weaker relation between sex and city size in the matched sample reflects, in part, the different compositions of the two samples. Table 1 (the Carnegie survey) covers only persons in teaching appointments. Table 3 (the matched sample of psychologists), although everyone in it had a teaching appointment in 1970, shows where they were in earlier years. Many of those positions were nonteaching academic appointments, administrative and postdoctoral, and some were nonacademic positions. In addition, the age distributions of men and women are not coincident in the Carnegie sample-the women are younger-and this may account for some of the discrepancy in results.

Nevertheless, the principal finding with respect to the residence patterns of men and women appears in both studies-women are located disproportionately in large urban centers. The Carnegie data indicate that much of this effect is attributable to the residence patterns of married women, presumably because their careers must evolve within the constraints of two-career households. We take this tendency to be an indicator of limitations on their freedom to make strategic job shifts to advance their careers. 


\section{Change of Institution and Migration}

Information regarding the rate of movement between geographic areas, when a change of institution occurs, provides our most compelling evidence for the constraints on the location options of women. In Table 4 we report the proportions of male and female psychologists in our matched sample who remained in the geographic areas of their graduate schools upon entering first jobs (30). It is evident that women were considerably less mobile than men, even at this early stage in their careers. On average, the women were half again as likely as the men to remain in the community of their $\mathrm{Ph}$.D.-granting institution (46.2 percent versus 31.6 percent for men). The tendency to remain was especially high among women who took their degrees in the largest cities; moreover, at that point women were already overrepresented in those communities $(73 / 199=37$ percent, as compared with $57 / 206=28$ percent for men).

The difference between men and women in migration rates is especially pronounced when all job shifts (that is, changes in institutional affiliation) are considered. In Table 5 we report on the percentage of job shifts that were made within the urban area during the 8- to 15year interval each psychologist was in our sample. It should be noted that the unit of analysis here is the job shift, not the individual. Sample members differ in number of job shifts contributed to our calculations, in accordance with the amount of institutional change they experienced during this period in their work lives and with the year of receipt of their doctorates.

Although the total number of job shifts is similar for men and women (286 versus 269), the greater tendency of the women to remain in the same urban area is quite pronounced-twice as great as that of the men. Except for the very smallest city-size category, the constraints upon women appear to be more severe in small job markets. In particular, while only 7.1 percent of men in cities of 100,000 to 1 million remained in the same area when changing jobs, the comparable figure for women was 33.3 percent.

At this point we have exhibited a rather consistent pattern in the geographic preferences of men and women. Academic women are both (i) more likely to locate in large urban centers and (ii) less prone to move, wherever they reside, as they tend to change institutions mainly within their areas of residence. Job shifts within a locale do not require a 21 SEPTEMBER 1979
Table 6. Positions held by psychologists of each sex in eighth year after receiving Ph.D. [Data from (24)]

\begin{tabular}{|c|c|c|}
\hline Type of position & $\begin{array}{c}\text { Men } \\
(\%) \\
N= \\
207\end{array}$ & $\begin{array}{c}\text { Wo- } \\
\text { men } \\
(\%) \\
N= \\
207\end{array}$ \\
\hline \multicolumn{3}{|l|}{ Academic, tenure track } \\
\hline Professor & 18.3 & 11.6 \\
\hline Associate professor & 48.3 & 34.3 \\
\hline Assistant professor & 13.5 & 25.1 \\
\hline \multicolumn{3}{|l|}{ Academic, nontenure track } \\
\hline Postdoctoral & 1.0 & 0.5 \\
\hline Lecturer, research associate & 3.9 & 11.1 \\
\hline Instructor & 3.9 & 3.4 \\
\hline Administrative & 0.5 & 1.0 \\
\hline Other & 3.4 & 4.4 \\
\hline Nonacademic & 7.2 & 6.7 \\
\hline No position reported & 0.0 & 1.9 \\
\hline
\end{tabular}

complementary job change by spouse or other family dislocations; we presume that this fact accounts for the differences in geographic movement between men and women. Thus, the familiar picture of the "mobile professor," taking whatever job best leads to advancement in position or salary, is less characteristic of female than male academics.

\section{Career Advancement}

To introduce our discussion of the effects of differential geographic mobility on career advancement, we report in Table 6 the job distributions of men and women in our matched sample of psychologists 8 years after completing the Ph.D. Most are seen to be in academic institutions and in tenure-track positions; this, however, is an artifact of the manner in which our sample was constructed, since holding a teaching position in 1970 was a requirement for inclusion. The lower representation of women in tenure-track positions (71 percent versus 80.1 percent for men) is not, however, derivative of the sample design, nor is the considerable underrepresentation of women in the higher ranks of associate professor and professor (45.9 percent versus 66.6 percent for men).

Similar data have been reported by others [for example $(5$, p. 189; 10, 31)] and they are consistent with the argument that there is institutional discrimination as well as with the argument that women's options are restricted by marriage. As we have noted, there are reasons to believe that constraints on movement in academia should retard career development. It is difficult, however, to ascertain the extent to which this factor is responsible for the lower attainments of women. In part this is because we lack data with which to relate type of geographic move to, for example, change in earnings. In part, the problem is also that many Ph.D.'s in our sample held nonacademic jobs at some point in their careers. These positions are difficult to place in a clear hierarchy of "achievement,' relative to each other and to academic positions, to determine the gains in status from a move. Additionally, several nontenure-track academic positions, such as assistant deanship or the rank of lecturer, carry varying degrees of prestige and remuneration.

We can nonetheless draw some tentative conclusions regarding the consequences of presumed two-career households for the academic standings of women. If we restrict ourselves to status shifts accompanying institutional changes that involve only the ranks of assistant professor, associate professor, and professor, we have an unambiguous hierarchy in status. (There remains the matter of institutional quality; many individuals leave an assistant professorship to take an associate professorship at a weaker institution. However, we will not dwell on this issue since our sample is too small to permit consideration of this or other possible second-order effects.)

In Table 7, upper panel, we report rank shifts which accompanied institutional changes, for instances where the positions could be ordered unambiguously. Changes which involved moving to a different community tended to be substantially more profitable for males than for females. In particular, 40 percent of men who moved between urban areas attained a higher academic rank in the process; the comparable figure for women was 23.3 percent $(P<.05$, onetail test). Women who moved within an urban area appear to have done slightly better than migrating women (29.4 percent versus 23.3 percent, not significant at the .10 level); such shifts are likely to be voluntary (32), at least in the sense of not being prompted by a husband's career requirements. Movement within an urban area by males was quite rare; only four institutional changes of this sort occurred in our male sample. The common pattern for the men was to move up by moving around.

In the lower panel of Table 7 we present analogous data for instances in which the job relinquished in a change of institutions was not on the tenure track. These data are more difficult to interpret, as there is no clear specification of "'higher rank,", "'same rank,', or "'lower 
rank" that might be assigned to status shifts. For this reason we report destination positions rather than an evaluation of the status shift. Nevertheless, this panel does provide support for our basic argument that men are more likely than women to be getting job advancements when they change community. If we view tenure-track positions as more desirable than jobs not on the tenure track or nonacademic jobs, then migrating women fared relatively poorly; 54.3 percent remained in their origin status category, versus 44.4 percent for men $(P$ $<.10$, one-tail test). The proportion of all geographic moves that resulted in high academic rank (associate professor or professor) was also lower for women (21.2 percent versus 27 percent for men), but the difference is not statistically significant (.10 level).

These findings support the notion that change of locale is more closely associated with a status improvement for men than it is for women. Because men are willing to make strategic moves, they tend to make job shifts to the most profitable alternatives. We would predict that even where men stay in the same geographic area when changing institutions, they do so because their best job options happen to be in the locale (33). Women, on the other hand, do less well whether they move or not, since many of them do not choose a location for the purpose of maximizing their own career prospects (34).

Table 7. Status change associated with employment shifts of psychologists of each sex. Unit of analysis is a pair of positions ("origin" and "destination") for an individual. Distributions are in percent. [Data from (24)]

\begin{tabular}{lccccc}
\hline \multicolumn{5}{c}{ A. Origin position: assistant or associate professor } \\
\hline $\begin{array}{l}\text { Location of } \\
\text { destination } \\
\text { position }\end{array}$ & $N^{*}$ & $\begin{array}{c}\text { Higher } \\
\text { rank }\end{array}$ & $\begin{array}{c}\text { Same } \\
\text { rank }\end{array}$ & $\begin{array}{c}\text { Lower } \\
\text { rank }\end{array}$ & $\begin{array}{c}\text { Nontenure track } \\
\text { or nonacademic }\end{array}$ \\
\hline $\begin{array}{l}\text { Different urban area } \\
\quad \text { Men }\end{array}$ & 35 & 40.0 & 45.9 & 1.2 & 12.9 \\
$\quad \begin{array}{l}\text { Women } \\
\text { Same urban area }\end{array}$ & 60 & 23.3 & 46.7 & 3.3 & 26.7 \\
$\quad$ Men \\
Women
\end{tabular}

B. Origin position: nontenure track or nonacademic

\begin{tabular}{lrrrrr}
\hline \multirow{2}{*}{$\begin{array}{c}\text { Location of } \\
\text { destination } \\
\text { position }\end{array}$} & $N^{*}$ & \begin{tabular}{c} 
Pro- \\
\cline { 3 - 5 }
\end{tabular} & $\begin{array}{c}\text { Associate } \\
\text { professor }\end{array}$ & $\begin{array}{c}\text { Assistant } \\
\text { professor }\end{array}$ & $\begin{array}{c}\text { Nontenure track } \\
\text { or nonacademic }\end{array}$ \\
\hline $\begin{array}{l}\text { Different urban area } \\
\quad \text { Men }\end{array}$ & 126 & 4.8 & 22.2 & 28.6 & 44.4 \\
$\quad \begin{array}{l}\text { Women } \\
\text { Same urban area }\end{array}$ & 94 & 7.4 & 13.8 & 24.5 & 54.3 \\
$\quad$ Men & 58 & 1.7 & 12.1 & 20.7 & 65.5 \\
$\quad$ Women & 96 & 2.1 & 10.4 & 32.3 & 55.2 \\
\hline
\end{tabular}

*Number of pairs of positions.

1230 (discrimination by colleges and universities). How much of the gap in attainment between the sexes should be attributed to the processes we have stressed, and how much to institutional discrimination, remains an open question (36).

There are several reasons why it is important to recognize the sources of women's disadvantage in academia. First, there is the matter of holding universities properly accountable for inequities that are the result of their actions, and insisting on recompense. Second, there is the question of how to assess sexism in hiring by specific educational institutions. On the basis of the foregoing analysis we would argue that the use of simple national production rates of Ph.D.'s by discipline as an index of "availability" may place an unfair burden on some institutions while letting the discriminatory practices of others go unpunished. $\mathrm{Na}$ tional figures do not represent the true availability of female and male academics to specific institutions. In particular, they overstate the supply of women to institutions in small labor markets and understate the supply to institutions in large labor markets. Further, salaries, rates of promotion, and other rewards to female academics may not be comparable with those of equally situated and productive males for reasons other than discrimination. Inability to seize strategic opportunities because of a lack of geographic flexibility may have negative effects on all these outcomes.

Differences between male and female academics with regard to geographic mobility may well decline in the future; we expect male academics to be subject increasingly to the pressures currently felt by females. As women insist on utilizing their training, and undertake careers, more academic men will find themselves in two-career households. They, too, will need large labor markets and be unable to change geographic locations with impunity.

Finally, we point out that while the underrepresentations of ethnic minorities and women are frequently discussed together, as different facets of institutional discrimination (37), our analysis indicates that they have different underlying causes, and should be analyzed separately. The processes we have documented with respect to women would not be relevant to the situations of male members of minority groups. Equally, the disadvantaged economic backgrounds of blacks and individuals of Spanish surname hardly applies to the circumstances of white academic women.

SCIENCE, VOL. 205 
References and Notes

1. The 1972 Equal Employment Opportunity Act and Executive Order 11246, as amended by Executive Order 11375

2. B. Sandler, Chron. Higher Educ. 7, 7 (1973).

3. H. S. Astin, The Woman Doctorate in America (Russell Sage Foundation, New York, 1969).

4. $\longrightarrow$ and A. E. Bayer, Educ. Rec. 53, 10

5. (1972).

J. Bernard, Academic Women (Pennsylvania State Univ., University Park, 1964)

6. J. A. Centra, Women, Men and the Doctorate (Educational Testing Service, Princeton, N.J. 1974)

7. L. R. Harmon, Profiles of Ph.D.'s in the Sciences: Summary Reports on Follow-Up of Doc toral Cohorts, 1935-1960-Career Patterns Report No. I (National Academy of Sciences Washington, D.C., 1965); Careers of Ph.D.'s Academic vs. Nonacademic-Career Patterns
Report No. 2 (National Academy of Sciences, Washington, D.C., 1968)

8. R. M. Oltman, Campus 1970: Where Do Women Stand? (American Association of University Women, Washington, D.C., 1970); A. S. Ross and A. Calderwood, Eds., Academic Women on 1973); H. Zuckerman and J. Cole, Minerva 13, 1973); $\mathrm{H}$.
85 (1975).

9. A. E. Bayer and H. S. Astin, Science 188, 796 (1975)

10. M. Patterson, Am Sociol 6, 226 (1971)

11. C. S. Stoll, Female and Male (Brown, Dubuque, Iowa, 1974).

12. After completing this paper, the authors came across an elegant mathematical formulation of of the empirical findings reported in our study [R. Frank, J. Polit. Econ. 86, 117 (1978)].

13. D. Brown, The Mobile Professors (American Council on Education, Washington, D.C. 1967), p. 36.

14. This is recognized in the HEW guidelines for Affirmative Action Programs, 14 August 1972 [B R. Lorch, Am. Sociol. 8, 116 (1973)]. For academic employees the basic national data on earned doctors degrees will provide the basis for utilization analysis of a contractor's work force, unless the contractor can otherwise demonstrate nificantly different from this base.

15. T. Caplow and R. J. McGee, The Academic Marketplace (Basic Books, New York, 1958) pp. 42-43.

16. In Centra's study ( 6, p. 114), 63 percent of the spouses of female Ph.D.'s held Ph.D.'s or professional degrees. The comparable figure for the spouses of male Ph.D.'s was 8.3 percent

17. T. Sowell, Public Interest 42, 47 (1976).

. For corroborating data on the extent change of community is undertaken principally ket, M. L. Robbins, L. Leive, A. S. Huang, Science 183, 493 (1974). For comments regarding the cost to wife's career from such relocation decisions see $(19)$

19. H. S. Astin, in Academic Women on the Move, Sage Foundation, New York, 1973). (Rp, 139 161.

20. B. F. Reskin, Am. Sociol. Rev. 41,609 (1976).

21. R. B. Curtis, The Invisible University: Postdoctoral Education in the United States (Na-
tional Academy of Sciences, Washington, D.C. 1969), p. 104

22. Exacerbating these difficulties in some places are formal antinepotism rules. Rossi [AAUP Bull. 59, 173 (1973)] reports that of 378 schools
on which she received information from chapon which she received information from chap-
ters of the American Association of University
Professors, 52 had strict institution-level policies against nepotism, 52 had departmental rules,
and 43 had unwritten departmental rules. In Centra's study $(6$, p. 46$), 9$ percent of the reponses by women and none of those by men to "Reasons for current unemployment?" were "Because of anti-nepotism policy of spouse's "employer."

23. Population of the urbanized area was used to characterize the geographic locations of degreegranting institutions and places of employment. We chose this areal unit instead of the smaller unit of central place (city) or the larger unit of Standard Metropolitan Statistical Area because it seemed to be the proper one for describing the locales within which people both live and work. Urbanized area sizes in the United States come from the 1960 U.S. Census. Information on sizes of Canadian communities come from the 1960 Canadian Census and for other countries from atlases. (Our second sample, to be described, contains a few instances where academics during parts of their

24. American Psychological Association, Biographical Directory, 1970 (American Psycho

25. Many longitudinal data are subject to error beMany longitudinal data are subject to error be-
cause of faulty recall. In the present investigation, however, the information obtained by the tion, however, the information obtained by the
APA from its 30,000 members should be a matter of record for those from whom it was reter of record for those from whom it was reto find additional information, we did notice occasional minor discrepancies between the two sources. The APA information was used for the sake of consistency and because it was more recent. On the whole, these data should be more reliable than retrospective surveys of the general population.

26. Of the 5098 women listed in the 1971-72 Survey of Women Members of the American Psychoof Women Members of the American Psycho-
logical Association 57 percent had Ph.D.'s, and 41 percent of all women psychologists reported teaching as one work activity. If a woman both teaching as one work activity. If a woman both
received a Ph.D. between 1955 and 1962 and listed teaching as one of the two work activities, her name was sought in the 1970 APA Biographical Directory. Of the women in the survey who ical Directory. Of the women in the survey who ten were nuns. They were omitted because inditen were nuns. They were omitted because indi-
viduals in religious orders do not always make viduals in religious orders do not always make
their own career decisions. For 125 others, the their own career decisions. For 125 others, the in the survey: their degree year was beyond the in the survey: their degree year was beyond the in 1970, or they did not list age and career information in the directory. These 125 were also excluded.

27. Men are overrepresented in psychology by a factor of 8 . Therefore only a sample of the eligible men was selected. The purpose of matching men to the women is to increase the efficiency of the sample for comparative analysis, as it permits cross-sex comparisons of movement and attainment within categories of the matching variables to be between equal-sized groups. What is sacrificed is an ability to assess the effects on the outcome measures of group differences in the variables used for matching, but those effects are not germane to our investigation.

The matching procedure was as follows: The joint distribution of women on the three variables was a given. From the women's sample a random individual was drawn to provide a starting point in the alphabet. The first male listed after her in the directory who fell into any cell of the cross-classification not yet filled was selected. This operation was repeated until the
women's sample was exhausted. In addition to providing a match between the men and women's samples on the three variables, this procedures stratifies on ethnicity and on other characteristics related to the alphabetical order of last

28. A. M. Cartter, An Assessment of Quality in Graduate Education (American Council on Education, Washington, D.C., 1966)

29. The bias which results from pooling marrieds and unmarrieds is on the conservative side. In particular, it underestimates the magnitude of the location differences between married women and others. This can be seen from an examination of Tables 1 and 2 . In the psychology segment of Table 2, the differences between married women and others in the over-2-million category is 35.1 percent minus a weighted average
of the percentage figures for the other marital of the percentage figures for the other marital
classes $(=20.6$ percent $)$, or 14.5 percent; the classes $(=20.6$ percent $)$, or 14.5 percent; the
comparable difference between men and women comparable difference between men and women (Table 1) is 32.4 percent minus 20.3 percent, or
12.1 percent. Thus, a comparison between men 12.1 percent. Thus, a comparison between men
and women underestimates the true effect. Analogous calculations for psychologists in the smallest city-size category yield the same result, as do replication total sample.

. In a few cases, an individual was not in residence at the time he or she finished work on the doctorate, but was employed in an area other than where the degree-granting institution is lograduate school may therefore have been made before the degree was received.

31. A. Rossi, Am. Sociol. 5, 1 (1970).

32. Though it is not statistically significant in our small sample, we interpret this effect since it is consistent with the pattern of our results.

33. A search of the directory for additional male psychologists who met the conditions for inclusion in the sample and who had made job in the same urban area revealed that their likelihood of advancement corresponded closely to that of males

4. The greater success of single than of married women in academia provides support for this notion. Astin (19, p. 153) reports that in her post-1940 cohorts 75 percent of single women post- 1940 cohorts 75 percent of single women
held the rank of associate professor or professor, as against 52 percent of married women. $\mathrm{Al}$ sor, as against 52 percent of married women. Al-
though such data tap all sources of disadvan-
tages which accrue to married women we sugtages which accrue to married women we sug gest that resil

35. Consistent with this argument, in a recent study of two-career families and migration R. P. Duncan and C. C. Perrucci [Am. Sociol. Rev. 41, 260 (1976)] conclude that "among college graduates, geographical movement is unfavorable to the wife's continued participation in the labor force.

36. These explanations are also confounded in a subtle way. An unsolicited job offer, even if rejected, will often result in an increase in remuneration and perhaps status at one's current institution. Because of perceptions of their immobility, married women are probably less likely than single women-or married men

37. See, for example, M. Jackson, Am. Sociol. 7 1972) and B. M. Vetter, Science 189, 75 (1975)

38. Data from the Carnegie Commission's 1969 survey of college and university faculty in the United States (see text)

39. Supported by funds granted to the Institute for Research on Poverty at the University of Wisconsin by the Office of Economic Opportunity, pursuant to provisions of the Economic Opportunity Act of 1964 . 